\title{
PENGEMBANGAN MEDIA PEMBELAJARAN BAHASA INGGRIS BERUPA FLASHCARD BERGAMBAR PADA TINGKAT SEKOLAH DASAR
}

\author{
Fitria Iswari \\ Desain Komunikasi Visual \\ Fakultas Bahasa dan Seni, Universitas Indraprasta PGRI \\ Jl. Nangka 58 Tanjung Barat, Jakarta Selatan, Indonesia \\ fitriaiswari@gmail.com
}

\begin{abstract}
Abstrak
Pada saat ini mata pelajaran Bahasa Inggris menjadi mata pelajaran tidak wajib. Dimana hanya mendapatkan alokasi waktu 2 jam dalam seminggu. Dalam hal tersebut menyebabkan pencapainan pembelajaran berjalan sedikit lamban. Tidak hanya menggunakan metode pengajaran yang baik namun juga menyediakan media yang baik untuk kegiatan belajar megajar. Mata pelajaran bahasa inggris pada tingkat SD/MI menekankan pada pengenalan kosakata sebagai pondasi atau dasar dalam pembelajaran bahasa inggris. Dari hasil survey di beberapa sekolah di Depok dan Kecamatan Tajurhalang Jawa Barat, para guru masih menggunakan cara tradisional dalam mempelajari kosakata baru yaitu menggunakan daftar kosakata baik yang ditulis di papan tulis maupun yang dicetak dibuku pelajaran siswa. Tujuan penelitian ini untuk menemukan efektifitas pengembangan media belajar flashcard. Penelitian ini menggunakan metode action research dengan pendekatan deskripsi kualitatif yang serta melibatkan 80 siswa dari 4 kelas yang memiliki jenjang berbeda. Hasil dari penelitian ni menunjukan bahwa pengembangan media gambar berupa flashcard memeberikan hasil yang lebih baik daripada penggunaan media belajar sebelumnya, yaitu mampu meningkat sebanyak $44 \%$ (dar nilai rata - rata 24,3 berubah menjadi 68,3 )
\end{abstract}

Kata Kunci : Pengembangan, media, Flashcard, Bahasa Inggris

\begin{abstract}
Nowdays English which is not as primary subject, has two hours in a week. It makes the learning goal is slower. In this case the teacher's role is important to get the best result in learning achievement. Not only apply the good teaching method but also provide the good media for teaching learning process. English at primary or Madrasah Ibtidaiyah school emphasis on Introducing of vocabulary which is a basic of English learning. Survey showes that there are some teachers in some school in Tajurhalang subdistrict and Depok, use traditional method by using vocabulary list that has written on the board or in the book. This aim of the study to find the effectiveness of the flashcard as learning media development. Action research with descriptive qualitative approach are adopted in this research which involve 80 students from 4 classes which have 2 different level to be tested. Research findings show that the development of learning media by using flash card gives the better result than the media of learning before the average scorecan increase $44 \%$ ( from 24,3 to 68,3 )
\end{abstract}

Key words : Development, media, flashcard, English.

\section{PENDAHULUAN}

\section{LATAR BELAKANG}

Bahasa dalam kehidupan manusia memiliki peranan yang penting dikarenakan bahasa adalah alat yang digunakan manusia untuk menyampai- kan informasi maupun maksud dan tujuan. Kemampuan berbahasa mampu mempengaruhi seseorang dalam mempelajari bidang yang lain. Penguasaan bahasa yang baik membuat seseorang mampu mengungkapkan, mengekspresikan ide, gagasan, dan tujuan secara baik 
kepada oranglain, oleh sebab itu kemampuan berbahasa yang baik sangat membantu seseorang dalam kehidupannya.

Bahasa Inggris memiliki kedudukan sebagai bahasa internasional bagi masyarakat Indonesia. kemampuan Bahasa Inggris menjadi modal dasar seseorang dalam persaingan di era global. Kebutuhan akan Bahasa Inggris telah difasilitasi sejak sekolah dasar (SD) hingga perguruan tinggi. Pada tingkat sekolah dasar Pada tingkat sekolah dasar pembelajaran bahasa inggris masih sebatas pengenalan kosakata (vocabulary). Karena penguasaan kosakata menjadi syarat penting dalam berbahasa asing seperti yang diungkapakan oleh John Read yaitu "The more words you have in your written or spoken vocabulary, the greater are the possibilities of your success in academics, business, and careers" (John Read, 2000), yang dapat diartikan penguasaan kosakata yang lebih banyak dalam kosakata lisan maupun tulisan, lebih besar kemungkinan untuk sukses dalam bidang akademis, bisnis, dan karier.

Fungsi dan tujuan pendidikan sebagaimana disebutkan dalam Undang - undang no 20 tahun 2003 pasal 3 dapat tercapai dengan peran serta tenaga pendidik dalam menunjang penyelenggaraan pendidikan yang berkualitas. Dari penjelasan tersebut jelas bahwa peran seorang guru sangat penting dalam proses pembelajaran siswa tingkat sekolah dasar baik secara pengadaan materi serta media belajar yang menarik dan memudahkan siswa dalam belajar bahasa inggris.

Dari berbagai media belajar yang tersedia, media flashcard merupakan salah satu media yang dapat digunakan sebagai alat bantu dalam memepelajari bahasa inggris. Seperti yang diungkapkan Djamarah bahwa media sebagai alat bantu dalam proses belajar mengajar adalah suatu kenyataan yang tidak dapat dipungkiri (2006: 121). Dari pernyataan tersebut jelas bahwa peran media penting dalam proses pembelajaran guna mendapat hasil yang terbaik. Hal ini menjadi penting terutama untuk proses belajar Bahasa Inggris yang menjadi bahasa asing dan jarang dingar di kehidupan sehari -hari. Siswa perlu mengetahui dan belajar keterampilan bahasa saat duduk di sekolah dasar supaya menjadi generasi unggul yang mampu bersaing dalam dunia internasional.

Seperti artikel yang ditulis oleh Miftachul Ula yang berjudul "PENGARUH PENGGUNAAN MEDIA FLASH CARD TERHADAP KEMAMPUAN MENGENAL HURUF PADA ANAK KELOMPOK A RA ROUDLOTUL ISLAMIYAH SIDOARJO“ yang menunjukan hasil bahwa terdapat pengaruh yang signifikan terhadap kemampuan anak dalam mengenal huruf. Sekolah Dasar Ragamukti adalah sekolah yang berada di kabupaten Bogor yang masih menggunakan cara tradisional yaitu menuliskan pada papan tulis, kemudian siswa mencatat dan diminta menghafal kosakata tersebut. Pada saat dilakukan pretest hasil yang didapat kurang memuaskan, Dari paparan tersebut penulis ingin menggunakan media gambar flashcard pada pengajaran Bahasa Inggris pada tingkat SD, oleh karena itu hal ini yang menjadi salah satu alasan kami untuk meneliti dan menulis artikel tentang pengembangan media pembelajaran dengan menggunakan media gambar flashcard.

Dalam artikel ini akan dibahas hasil penggunaan antara media gambar flashcard dan catatan guru yang ditulis di papan tulis. Diharapkan anilisis ini mampu melengkapi kekurangan analisis terdahulu. 


\section{TINJAUAN PUSTAKA Media Pembelajaran}

Media berasal dari kata "medium" yang berarti "tengah" " pengantar " yang berarti alat pengantar atau media dari sumber informasi kepada penerima informasi. Menurut Nurbiana Dhieni dkk., (2008: 10.3) menyatakan bahwa media adalah segala bentuk alat komunikasi yang dapat digunakan untuk menyampaikan pesan atau informasi dari sumber yang bertujuan agar dapat merangsang pikiran, perasaan, minat, dan perhatian penerima pesan atau informasi tersebut. . Media pembelajaran adalah wahana dari pesan oleh sumber pesan atau guru dan ingin diteruskan kepada penerima pesan yaitu anak (Badru Zaman dkk., 2009: 4.13). Dari uraian para ahli tersebut dapat disimpulkan media pembelajaran adalah segala bentuk alat bantu yang digunakan oleh guru di dalam proses belajar mengajar dengan tujuan mempermudah dalam pemberian informasi kepada peserta didik.

Berdasarkan uraian yang jabarkan sunarsih dalam Encyclopedia of Educational Research (dalam Sunarsih, 2011:11) merincikan manfaat media pendidikan sebagai berikut :

1. Meletakkan dasar-dasar yang konkret untuk berpikir, oleh karena itu mengurangi verbalisme

2. Memperbesar perhatian anak

3. Meletakkan dasar-dasar yang penting untuk perkembangan belajar, oleh karena itu membuat pelajaran lebih mantap

4. Memberikan pengalaman nyata yang dapat menumbuhkan kegiatan berusaha sendiri dikalangan anak

5. Menumbuhkan pemikiran yang teratur dan kontinyu, terutama melalui gambar hidup

6. Membantu tumbuhnya pengertian yang dapat membantu perkembangan kemampuan berbahasa
7. Memberikan pengalaman yang tidak mudah diperoleh dengan cara lain, dan membantu efisiensi dan keragaman yang lebih banyak dalam belajar.

\section{Media Belajar Flashcard}

Flash card adalah media pembelajaran visual yang berisi katakata, gambar, atau kombinasinya (Basuki Wibawa \& Farida Mukti, 1991: 30). Hal ini sesuai dengan pengertian flashcard menurut Menurut Dina Indriana (2011: 68-69) flash card adalah media pembelajaran dalam bentuk kartu bergambar yang berukuran $25 \mathrm{~cm}$ x 30 $\mathrm{cm}$. Gambar yang ditampilkan dapat berupa gambar tangan atau foto yang sudah ada kemudian ditempelkan pada lembaran-lembaran kartu. Sedangkan menurut Azhar Arsyad (2011: 120-121), flash card adalah kartu yang berisikan gambar-gambar (benda, binatang, dan sebagainya) yang dapat digunakan untuk melatih anak mengeja dan memperkaya kosa kata. Dari pengertian flashcard tersebut menurut peneliti flashcard adalah kartu bergambar yang memuat foto atau gambar dihalaman depan dan terdapat keterangan kosakata sesuai gambar pada halaman depan serta keterangan cara membacanya.

Dalam hal ini peneliti mempertimbangkan menggunakan media flashcard dikarenakan media tersebut memiliki beberapa kelebihan, seperti yang diutarakan oleh Indriana bahwa media flashcard: (1) mudah dibawa kemana-mana karena ukurannya seukuran postcard, (2) praktis dalam membuat dan menggunakannya, sehingga kapanpun anak didik bisa belajar dengan baik menggunakan media ini, (3) mudah diingat karena kartu ini sangat menarik, berisi huruf atau angka, simpel, merangsang otak lebih lama mengingat pesan pada kartu, (4) sangat menyenangkan digunakan sebagai media pem- 
belajaran, dalam bentuk permainan (Indriana, 2011:68-69). Dalam hal ini flashcard dapat pula dijadikan sebuah permainan karena sifatnya yang menyenangkan. Dari pengertian tersebut dapat disimpulkan kelebihan flashcard antara lain praktis, mudah diingat, serta menyenangkan.

\section{Pembelajaran Bahasa Inggris Tingkat Sekolah Dasar /MI}

Pembelajaran bahasa inggris sebenarnya cukup penting dalam dunia pendidikan mengingat bahasa inggris adalah bahasa internasional yang digunakan banyak Negara di seluruh dunia. Pada kurikulukulum 2006 bahasa inggris menjadi salah satu mata pelajaran wajib dalam tingkat SD, namun dalam kurikulum 2013 kedudukan mata pelajaran bahasa inggris bergeser menjadi muatan lokal dan ekstrakulikuler. Menurut Brown ada beberapa prinsip dalam proses pembelajaran bahasa inggris, yaitu terdapat dua belas pengajaran bahasa yang meliputi kognitif: (1) Otomatisasi, (2) Pembelajaran bermakna, (3) antisipasi penghargaan, (4) Motivasi instrinsic, (5) Investasi strategis, afektif yaitu : (6) ego bahasa, (7) percaya diri, (8) pengambilan resiko, (9) hubungan bahasa dan budaya, (10) pengaruh bahasa ibu, (11) antar bahasa, dan (12) kompetensi komunikatif (Brown: 2007). Dari poin no dua tertulis pembelanjaran bermakna, dalam hal ini flashcard memiliki kelebihan menyenangkan, dengan kata lain pembelajaran bahasa inggris ini mampu menjadi bermakna bagi siswa.

1. Selanjutnya Pinter (2006: 38) mengatakanbahwa maksud dan tujuan program pembelajaran bahasa inggris di SD adalah :

2. Mengembangkan kemampuan komunikasi dasar dalam bahasa inggris.
3. Mendorong kesenangan dan motivasi

4. Mempromosikan belajar mengenai budaya - budaya lain

5. Mengembangkan keterampilan kognitif anak

6. Mengembangkan kesadaran metalinguistik

7. Mendorong pengetahuan pelajaran untuk belajar

Dalam kurikulum 2006 Depdiknas (2006) mengatakan bahwa mata Pelajaran Bahasa Inggris SD/MI bertujuan agar peserta didik memiliki kemampuan sebagai berikut : (1) mengembangkan kompetensi berkomunikasi dalam bentuk lisan secara terbatas untuk mengiringi tindakan ( language accompanying action) dalam konteks sekolah, (2) memiliki kesadaran tentang hakikat dan pentingnya bahasa inggris untuk meningkatkan daya saing bangsa dalam masyarakat global, sedangkan ruang lingkup pembelajaran bahasa inggris pada tingkat SD/MI mencakup kemampuan komunikasi secara terbatas meliputi kemampuan : (1) membaca, (2) menulis, (3) mendengarkan, (4)berbicara. Dalam prosesnya pembelajaran bahasa inggris pada tingkat SD/MI masih memfokuskan pada pengenalan kosa kata meliputi lingkungan di sekitar kita, seperti: sekolah, rumah, taman bermain, kebun binatang, perpustakaan dan sebagainnya.

\section{METODOLOGI PENELITIAN}

Metode yang digunakan dalam penelitian ini adalah metode tindakan kelas (action research). Dalam bahasa inggris metode penelitian ini disebut classroom action research. Dalam penelitian ini peneliti melakukan ujicoba terhadap sampel kemudian mendeskripsikan, menginterpretasi, dan menjelaskan hasil temuan kemudian 
dilakukan perbaikan untuk hasil yang lebih baik.

Terdapat makna pada kata penelitian tindakan kelas menurut Arikunto (2007: 2-3). : yaitu :

1. Penelitian menunjuk pada suatu kegiatan mencermati suatu objek denganmenggunakan cara dan aturan metodologi tertentu untuk memperoleh data atau informasi yang bermanfaat dalam meningkatkan mutu suatu hal yang menarik dan penting bagi peneliti.

2. Tindakan menunjuk pada suatu gerak kegiatan yang sengaja dilakukan dengan tujuan tertentu. Dalam penelitian berbentuk rangkaian siklus kegiatan untuk siswa.

3. Kelas dalam hal ini tidak terkait pada pengertian ruang kelas, tetapi dalam pengertian yang lebih spesifik. Seperti yang sudah lama dikenal dalam bidang pendidikan danpengajaran, yang dimaksud dengan istilah kelas adalah sekelompok siswa yang dalam waktu yang sama, menerima pelajaran yang sama dari guru yang sama pula.

Sesuai dengan definisi para ahli tersebut dapat diambil kesimpulan bahwa penelitian tindakan kelas adalah perwujudan gagasan yang direalisasikan dalam bentuk tindakan di dalam kelas pada proses pembelajaran untuk menemukan bukti atau gagasan baru berdasarkan teori yang dibuat.

1. Tujuan penelitian tindakan adalah kelas menurut Soeparno (2008:17) adalah :

2. Untuk melakukan perubahan atau peningkatan praktek pendidikan yang teliti secara lebih langsung

3. Untuk mendekatkan hasil penelitian dengan praktek guru di lapangan sehingga berdasarkan hasil riset guru dapat emperbaiki kinerjanya.
4. Mengembangkan profesionalitas para pendidik dalam lingkungan kerja.

Penelitian ini dilakukan di sekolah dasar yaitu SD Negri Ragamukti yang beralamat Desa Citayam, Kecamatan ragamukti Kabupaten Bogor.Subjek penelitian Ini adalah siswa kelas 3 dan kelas 4 sekolah dasar SDN Ragamukti yang melibatkan 2 rombongan belajar (rombel).

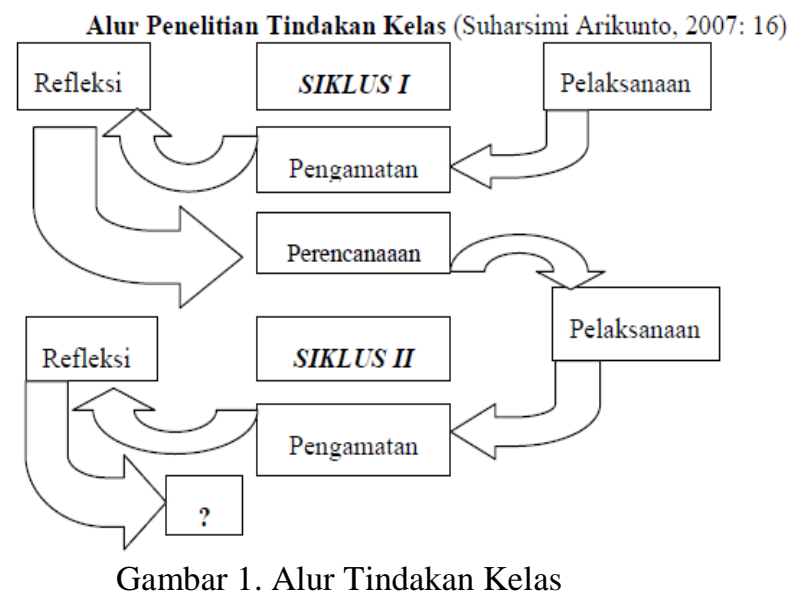

Dalam penelitian tindakan kelas terdapat tahapan untuk mendapatkan hasil dari gagasan yang dilakukan menurut (Suharsimi, Arikunto, 2007: 1620) yaitu:

1. Perencanaan

2. Pelaksanaan

Tahap pelaksanaan tindakan kelas ini diharapkan tidak terlalu dibuat buat, langkah - langkah tersebut adalah :

a. Dalam 1 kelas peneliti membagi siswa kedalam sebuah kelompok yang terdiri dari 6 orang.

b. Peneliti membagikan daftar kosakata dalam waktu 15 menit, kemudian masing - masing siswa diminta mengingat.

c. Setelah 15 menit peneliti akan melakukan test kepada siswa dengan cara meminta menyebutkan kosakata yang diberikan. 
d. Masih dalam kelompok yang sama peneliti membagikan flashcard berjumlah 30 kepada tiap kelompok. Kemudian selama 15 menit siswa diminta untuk menghafal, setelah 15 menit siswa diminta untuk menyebutkan kosakata tersebut berdasarkan gambar pada flashcard.

3. Pengamatan

4. Refleksi.

Data yang didapat memalui beberapa sumber, yaitu : (1) Skor test hasil observasi yang dilakukan pada saat tindakan kelas berlangsung, (2) Hasil wawancara mengenai pembelajaran Bahasa Inggris dengan menggunakan media flashcard.

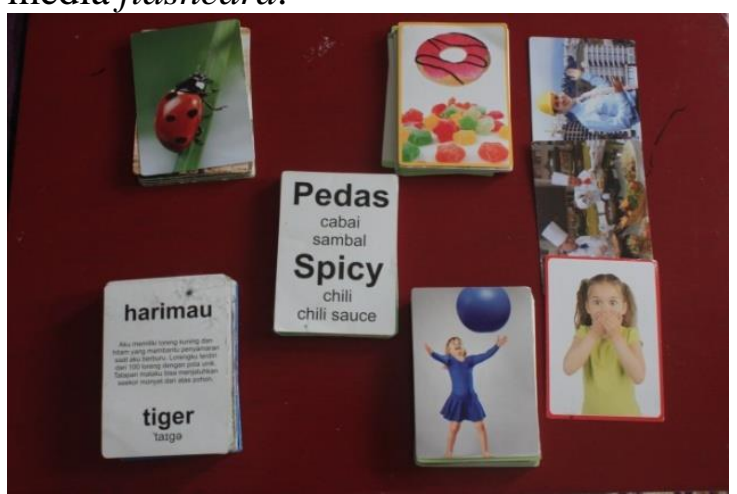

Gambar 2. Media Gambar flashcard Yang Digunakan dalam Penelitian

Dalam penelitian ini Instrument yang digunakan adalah: (1) Lembar Observasi (daftar skor yang diperoleh siswa), (2) Lembar Wawancara, (3) Dokumentasi. Penelitian tindakan kelas ini merupakan penelitian yang bersifat kualitatif, namun data dari nilai berupa score, peniliti menggunakan data kualitatif dan kuantitatif dalam menganalisa data dengan mengunakan pendekatan deskriptif. Peneliti menggunakan data berupa score yang berasal dari hasil tes. Dengan score tertinggi adalah 100, sedangkan score rata-rata siswa dapat dihitung dengan menggunakan rumus :

$$
x=\frac{\sum x}{N} \quad \begin{aligned}
\mathrm{x} & =\text { nilai rata-rata } \\
\sum \mathrm{x} & =\text { jumlah skor keseluruhan } \\
\mathrm{N} & =\text { jumlah siswa }
\end{aligned}
$$

Hasil score akan dimasukan kedalam tabel frekuensi kemudian dilanjutkan dengan analis deskripsi. Keberhasilan penelitian tindakan kelas ditunjukan dengan adanya perubahan yang lebih baik. Hal ini ditunjukan dengan adanya peningkatan skor / nilai yang diperoleh siswa setelah menggunakan media gambar flashcard. Dalam tindakan kelas yang pertama siswa hanya menggunakan daftar kosakata yang ditulis dipapan ataupun yang dicetak dalam lembaran kertas. Selanjutnya metode tindakat dengan menggunakan media gambar flashcard.

\section{PEMBAHASAN}

Pada penelitian ini selain mengambil data melalui tindakan kelas peniliti juga mendapatkan data pendukung dari hasil wawancara terhadap peserta didik dan tenaga pengajar. Setelah menyelesaikan penelitian tindakan kelas, para peneliti mewawancarai 15 siswa SD Ragamukti kelas III dan kelas IV serta tenaga pendidik untuk mata pelajaran Bahasa Inggris. Setelah kami mewawancarai para siswa dan tenaga pendidik dengan memberikan 10 pertanyaan, kemudian membahas, dan menarik kesimpulan dari hasil wawancara, maka dapat disimpulkan bahwa :

1. Pendidik lebih sering menggunkan daftar kosakata (vocabulary list) yang ditulis di papan maupun yang terdapat di dalam buku.

2. Siswa membutuhkan waktu lebih singkat untuk mengingat kosakata apabila menggunakan flashcard. 
3. Sebagian besar siswa belum pernah melihat flashcard sebagai media dalam kegiatan belajar mengajar.

4. Siswa merasa lebih senang mempelajari kosakata dengan menggunakan flashcard dengan alas an penuh warna dan kegiatannya tidak membosankan.

5. Guru menemukan kendala yaitu dibutuhkanya jumlah flashcard yang cukup banyak apabila ingin digunakan dalam kegiatan belajar mengajar di dalam kelas karena jumlah siswa yang berjumlah 37 hingga 41 siswa.

Data di bawah ini adalah hasil Penguasaan Kosakata Bahasa Inggris Sebelum Menggunakan Media Gambar Flashcard.

Tabel 5.5 Tabel frekuensi nilai siswa kelas III dan IV sebelum menggunakan flashcard

\begin{tabular}{rrr}
\hline Nilai(X) & frekuensi(f) & Jumlah(f.X) \\
\hline 0 & 9 & 0 \\
\hline 7 & 12 & 84 \\
\hline 13 & 6 & 78 \\
\hline 20 & 7 & 140 \\
\hline 27 & 9 & 243 \\
\hline 33 & 3 & 99 \\
\hline 40 & 6 & 240 \\
\hline 47 & 4 & 188 \\
\hline 53 & 1 & 53 \\
\hline 60 & 2 & 120 \\
\hline 67 & 3 & 201 \\
\hline 87 & 1 & 87 \\
\hline Jumlah Nilai & & 1533 \\
\hline
\end{tabular}

Tabel frekuensi tersebut menunjukan nilai yang didapat siswa kelas III dan IV pada saat belum menggunakan media gambar flashcard. nilai terendah dalam kegiatan ini adalah 0 dan nilai tertinggi adalah 87 . Dengan rata - rata nilai keseluruhan sebagai berikut:

$\mathbf{X}=\frac{\Sigma \mathrm{X}}{\mathrm{N}}$

Keterangan :

$\mathrm{X}$ : Nilai rata - rata
$\Sigma x$ :Jumlah Nilai Keseluruhan

$\mathrm{N}$ : Total Siswa

$\mathrm{X}=\frac{1533}{63}=24,3$

Penguasaan Kosakata bahasa Inggris Setelah Menggunakan Media Gambar Flashcard

Tabel 5.6 Tabel frekuensi nilai siswa kelas III dan IV setelah menggunakan flashcard

\begin{tabular}{rrr}
\hline \multicolumn{1}{l}{ Nilai(X) } & frekuensi(f) & Jumlah(f.X) \\
\hline 33 & 5 & 165 \\
\hline 40 & 3 & 120 \\
\hline 47 & 5 & 235 \\
\hline 53 & 7 & 371 \\
\hline 60 & 9 & 540 \\
\hline 67 & 7 & 469 \\
\hline 73 & 3 & 219 \\
\hline 80 & 7 & 560 \\
\hline 87 & 4 & 348 \\
\hline 93 & 3 & 279 \\
\hline 100 & 10 & 1000 \\
\hline Jumlah Nilai & & 4306 \\
\hline
\end{tabular}

Tabel frekuensi tersebut diambil dari seluruh objek penelitian yaitu kelas III dan kelas IV setelah penggunaan media gambar flashcard. Tabel frekuensi ini berfungsi untuk mengetahui rerata keseluruhan nilai objek penelitian, Modus (nilai yang sering muncul). Dari tabel fekuensi di atas dapat disimpulkan nilai terendah adalah 33 dengan nilai tertinggi 100 . Sebelum menggunakan flashcard nilai terendah yang didapat siswa adalah 0 , dan serta nilai tertinggi 87. Dengan Pencapaian nilai 100 hal ini menunjukan bahwa media gambar flashcard berperan penting dan sangat berguna dalam kegiatan belajar mengajar dalam pembelajaran kosakata Bahasa Inggris di tingkat Sekolah Dasar. nilai yang sering muncul ialah 100 dengan jumlah siswa 10 orang. Dengan rerata nilai seluruhnya, yaitu :

$\mathbf{X}=\frac{\Sigma \mathrm{X}}{\mathrm{N}}$ 
Keterangan :

$\mathrm{X}$ : Nilai rata - rata

$\Sigma x$ :Jumlah Nilai Keseluruhan

$\mathrm{N}$ : Total Siswa

$X=\frac{4306}{63}=68,3$

Dari data yang telah diterangkan di atas bahwa rata - rata nilai siswa SD Ragamukti sebelum menggunakan media gambar flashcard adalah sebesar 24,3 dan setelah menggunakan media flashcard meningkat menjadi 68,3 .Hal ini terlihat lebih jalas dalam uraian persentase di bawah ini:

Persentase Nilai $=$ Selisih nilai X 100\%

$$
\begin{aligned}
& =44 \times 100 \% \\
& =44 \%
\end{aligned}
$$

Nilai persentasi yang melebihi $25 \%$ dan mendekati $50 \%$ ini dianggap berhasil meningkatkan kemampuan kosakata Bahasa Inggris siswa kelas III dan IV dengan pengembangan media belajar flashcard.

Setelah melakukan tindakan kelas dengan media flashcard dan terjadi peningkatan nilai dalam penguasaan kosakata sebesar 44\%. Hal ini sudah dianggap cukup berhasil dalam pengembangan media pembelajaran berupa media gambar flashcard yang diterapkan pada siswa tingkat sekolah dasara Ragamukti. Dikarenakan pada siklus pertama dalam penelitian ini telah berhasil, oleh sebab itu para peneliti meneliti hingga tahap 1 dan penelitian ini telah selesai. Dari uraian dan pembahasan di atas pengembangan media pembelajaran berupa flashcard sangat diperlukan dikarenakan flashcard banyak membantu siswa dan jauh lebih efisien serta efektif apabila digunakan sebagai alat bantu atau media pembelajaran dalam mempelajari kosakata Bahasa Inggris dibandingkan dengan menggunakan daftar kosakata ( vocabulary list) baik yang ditulis dipapan tulis maupun yang terdapat dalam buku peserta didik. Bukan hanya memiliki sifat efektif dan efisien media gambar flashcard ini membuat siswa lebih senang dan bersemangat dalam mempelajari kosakata karena dapat digunakan sebagai permainan edukatif di dalam kelas.

Media pembelajaran untuk mata elajaran Bahasa Inggris yang awalnya lebih sering menggunakan daftar kosakata (vocabulary list) atau yang biasanya ditulis di papan tulis maupun yang sudah terdapat di dalam buku siswa menunjukan nilai yang lebih rendah dibandingkan menggunakan media gambar flashcard. Peningkatan nilai setelah menggunakan media flashcard ialah 44\%, angka tersebut adalah angka yang cukup signifikan mengingat penelitian tindakan yang dilakukan 1 kali. Apabila dilakukan berkali - kali, dan secara terus menerus akan mendapatkan hasil yang lebih baik.

Dari temuan tersebut pengembangan media visual berbentuk flashcard yang memiliki gambar dan warna yang beragam dirasa penting dilakukan oleh tenaga pendidik yang mengajar mata pelajaran Bahasa Inggris. Media yang awalnya hanya berupa tulisan yang ditulis dipapan ataupun yang sudah terdapat pada buku cetak dapat dikembangkan pada sebuah kartu bergambar yang jauh lebih menarik, sehingga dapat mudah diingat oleh peserta didik.

\section{SIMPULAN}

Setelah dilakukan penelitian berupa tindakan kelas, pengambilan data, serta dilakukan pembahasan maka kesimpulan yang dapat diambil dari penelitian pengembangan metode pembelajaran Bahasa Inggris berupa media gambar flashcard di SD RAGAMUKTI, yaitu:

1. Penggunaan metode pembelajaran Bahasa Inggris menggunakan daftar 
kosakata (vocabulary list) mendapatkan hasil nilai yang rendah yaitu dengan rerata nilai 24,3

2. Penggunaan metode pembelajaran Bahasa Inggris menggunakan media gambar flashcard mendapatkan hasil yang lebih tinggi dibandingkan menggunakan daftar kosakata (verblist) yaitu dengan nilai rata rata kelas sebesar 68,3

3. Peningkatan nilai setelah menggunakan metode pembelajaran berupa media gambar flashcard sebesar $44 \%$.

4. Siswa dan siswi sangat senang menggunakan media gambar flashcard dalam proses belajar dan pembelajaran Bahasa Inggris dikarenakan bentuk dan warna flashcard yang menarik serta cara penggunaannya yang menyerupai permainan.

5. Guru lebih sering menggunakan daftar kosakata yang ditulis di papan tulis maupun yang terdapat dalam buku atau lembar kerja siswa (LKS), kemudian mengajarkan cara pengucapan sebelum meminta siswa menghafal.

6. Guru mendapati kesulitan menggunakan media gambar flashcard sebagai metode baru dalam pembelajran kosakata karena membutuhkan flashcard dalam jumlah yang banyak.

7. Pengembangan metode berupa media gambar flashcard sangat membantu baik siswa maupun tenaga pendidik dibandingkan menggunakan daftar kosakata ( vocabulary list)

Ada beberapa rekomendasi yang diberikan terkait hasil penelitian ini. Pertama, Penelitian ini diharapkan memberikan masukan untuk tim MGMP tingkat kecamatan untuk diadakan pelatihan bagi tenaga pendidik dalam pengembangan metode pembelajaran berupa media gambar flashcard.

Kedua, penelitian ini diharapkan menjadi referensi bagi pemerintah untuk menyediakan media pembelajaran flashcard sesuai jumlah yang dibutuhkan sekolah.

Ketiga, Penelitian ini diharapkan memberi masukan kepada tenaga pendidik untuk menambahkan flashcard sebagai salah satu media pembelajaran yang digunakan dalam proses kegaiatan belajar mengajar.

\section{DAFTAR PUSTAKA}

Azhar Rasyad. (2011). Media Pembelajaran. Jakarta: Raja Grafindo Persada

Badru Zaman, Asep Hery Hernawan, \& Cucu Eliyawati. (2009). Media dan Sumber Belajar TK. Jakarta: Universitas Terbuka.

Basuki Wibawa \& Farida Mukti. (1991). Media Pengajaran. Jakarta: Departemen Pendidikan dan Kebudayaan, Direktorat Jenderal Pendidikan Tinggi, Proyek Tenaga Kependidikan.

Depdikbud,( 2013).,permendikbud No 81A 2013 Tentang Implementasi Kurikulum 2013, Jakarta: Depdikbud

Dina Indriana. (2011). Ragam Alat Bantu Media Pengajaran. Yogyakarta: Diva Press.

Nurbiana Dhieni, Lara Fridani, Gusti Yarmi, \& Nany Kusniaty. (2008). Metode Pengembangan Bahasa. Jakarta: Universitas Terbuka. 
Pinter, Annamaria,(2006),Teacching Young Language Learners, Oxford: Oxford University Press

Read,John (2000). Assessing vocabulary. Cambridge:

Cambridge University Press

Suharsini Arikunto, Suhardjono, \& Supardi. (2007). Penelitian Tindakan Kelas. Jakarta: Rineka Cipta.

Sunarsih. (2011). "Pemaanfaatan Media Jaring-Jaring Bangun Ruang
Tabung Untuk Meningkatkan Hasil Belajar Matematika". Skripsi Tidak Diterbitkan. Surabaya : Program Pendidikan Guru Sekolah Dasar

Suparno Paul, 2008, Action Research, Riset Tindakan Untuk Pendidik, Jakarta: Grasindo.

Syaiful Bahri Djamarah \& Aswan Zain. (2006). Strategi Belajar Mengajar. Jakarta: Rineka Cipta. 